\title{
Chemo-Enzymatic Epoxidation of Sunflower Oil Methyl Esters
}

\author{
Rosana de Cassia S. Schneider, ${ }^{*, a}$ Luciano R. S. Lara, ${ }^{a}$ Thiago B. Bitencourt, ${ }^{b}$ \\ Maria da Graça Nascimento ${ }^{b}$ and Marta R. dos Santos Nunes ${ }^{c}$
}

\author{
${ }^{a}$ Departamento de Química e Física, Universidade de Santa Cruz do Sul, 96815-900 Santa Cruz do Sul-RS, Brazil \\ ${ }^{b}$ Departamento de Química, Universidade Federal de Santa Catarina, 88040-900 Florianópolis-SC, Brazil \\ ${ }^{c}$ Centro de Ciências Exatas e Tecnologia, Universidade de Caxias do Sul, 95070-560 Caxias do Sul-RS, Brazil
}

\begin{abstract}
Foi realizada a epoxidação quimio-enzimática de ésteres metílicos do óleo de girassol, utilizando lipase em meio aquoso, na presença ou não de acil doadores. As reações no sistema bifásico $\left(\mathrm{CH}_{2} \mathrm{Cl}_{2} / \mathrm{H}_{2} \mathrm{O}\right)$ foram conduzidas utilizando-se a Candida antarctica lipase B (CALB, $1000 \mathrm{u} \mathrm{g} \mathrm{g}^{-1}$ ) e peróxido de hidrogênio a $30 \%$ (v/v). A conversão foi maior do que $99 \%$ em $16 \mathrm{~h}$ de reação. Os melhores resultados foram obtidos com o sistema bifásico, em tempo reacional de $16 \mathrm{~h}$, a $30^{\circ} \mathrm{C}, 10 \mathrm{mmol}$ de ácido octanóico em relação a $1 \mathrm{~g}$ de óleo, $6 \mathrm{~mL}$ de diclorometano e $5 \mathrm{~mL}$ de água, garantindo uma alta conversão dos ésteres e maior tempo de uso da lipase.
\end{abstract}

The chemo-enzymatic epoxidation of the methyl esters of sunflower oil with lipase from Candida antarctica $\mathrm{B}$ and aqueous $\mathrm{H}_{2} \mathrm{O}_{2}$ in the presence and absence of an acyl donor was investigated. The biphasic system $\left(\mathrm{CH}_{2} \mathrm{Cl}_{2} / \mathrm{H}_{2} \mathrm{O}\right)$ comprised Candida antarctica $B$ lipase (CALB, $\left.1000 \mathrm{u} \mathrm{g}^{-1}\right)$ and $30 \%(\mathrm{v} / \mathrm{v})$ aqueous hydrogen peroxide. In some cases the conversion was higher than $99 \%$. The best results were obtained for the biphasic system after $16 \mathrm{~h}$ of reaction, at $30^{\circ} \mathrm{C}$, using $10 \mathrm{mmol}$ of octanoic acid in relation to $1 \mathrm{~g}$ of the oil, $6 \mathrm{~mL}$ of dichlomethane and $5 \mathrm{~mL}$ of water.

Keywords: Candida antarctica B lipase, chemo-enzymatic epoxidation, sunflower oil, methyl esters, bioprocessing

\section{Introduction}

The environmental problems caused by the indiscriminate use and scarcity of petroleum are prompting researches to search for renewable resources, such as derivatives of vegetable oils. ${ }^{1-3}$

The use of renewable resources and biocatalysts is better for the environment. ${ }^{4}$ Biocatalysts, especially lipases (triacylglycerol acylhydrolase EC 3.1.1.3), are widely used in synthetic organic chemistry. They are readily available from microbial and mammalian sources, and some of them are extremely robust and stable under relatively extreme temperature, $\mathrm{pH}$, and solvent conditions. ${ }^{5,6}$

The potential of lipases in the oleochemistry industry has been explored recently. ${ }^{6,7-10}$ Lipases are capable of hydrolyzing triacylglycerols, producing free fatty acids, which, in the presence of hydrogen peroxide, form the corresponding peracids. These peracids can be used to form

\footnotetext{
*e-mail: rosana@unisc.br
}

oxirane rings in the double bonds of hydrocarbon chains of fatty acids. ${ }^{11,12}$

In industry, epoxidation using the Prileshajev method has previously been applied to the conversion of double bonds into the corresponding oxirane rings of vegetable oils using classical acid catalysts. ${ }^{13}$

In 1990, Björkling et al..$^{14}$ published the first results related to chemo-enzymatic epoxidation. Later, progress was made towards reducing the limitations of industrial scale syntheses by making the procedure a more environmentally acceptable alternative for vegetable oil transformations. ${ }^{15-18}$

Epoxides are of great industrial interest because they are intermediate compounds for the production of polymers, adhesives, resins, and other materials. This versatility is associated with the high reactivity of the oxirane ring. Specifically, fatty epoxides are used directly as plasticizers and plastic stabilizers or appear as reaction intermediates. They are also useful intermediates in the synthesis of other materials. ${ }^{1,19,20}$ Epoxides, as well as other oleochemistry 
products, are applicable to various syntheses with high added value.

When using this biocatalyst, it is important to prevent lipase denaturation in the presence of organic solvents, hydrogen peroxide, or the formed peracid. . $^{16,21,22}$

In biocatalyzed reactions, enzymatic activity may also be lost due to elevated concentrations of hydrogen peroxide or to temperature effects. However, some recent papers have shown that Candida antarctida B lipase remained stable above $50{ }^{\circ} \mathrm{C}$, although this was not favorable, mainly due to the decomposition of hydrogen peroxide. Furthermore, at higher temperatures, the enzyme acquires a more open conformation, possibly increasing the accessibility to sensitive amino acids in the inner regions of the enzyme, and thus decreasing its catalytic activity. ${ }^{16}$

An alternative method for the reduction of lipase denaturation is the use of a biphasic system (water/organic solvent), because the enzyme remains protected in the aqueous phase.

In this paper, the chemo-enzymatic production of epoxides derived from methyl esters of sunflower oil (Helianthus annus $L$.) with lipase from C. antarctica $\mathrm{B}$ and aqueous $\mathrm{H}_{2} \mathrm{O}_{2}(30 \%)$ in the presence and absence of an acyl donor (caprylic acid) is presented (Figure 1).

The use of a biphasic system $\left(\mathrm{CH}_{2} \mathrm{Cl}_{2} / \mathrm{H}_{2} \mathrm{O}\right)$ is also compared with the monophasic system $\left(\mathrm{CH}_{2} \mathrm{Cl}_{2}\right)$.

\section{Experimental}

\section{Material and methods}

The refined sunflower oil (Valore, Brazil) contained oleic (C18:1) 27\%, stearic (C18:0) 6\%, palmitic (C16:0) 9\%, linoleic (C18:2) 57\%, and linolenic acids (C18:3) $0.3 \%$. Boron trifluoride-methanol $\left(\mathrm{BF}_{3} \cdot \mathrm{MeOH}, 14 \% \mathrm{~m} / \mathrm{V}\right)$ was purchased from Acros Organics (Fairlawn, NJ), and hexane, ethyl acetate, dichloromethane, and deuterated chloroform (99.8\% pure) were purchased from Merck (Hohenbrunn, Germany). These were used as received. All solvents were of analytical reagent grade and used without any pretreatment. The methyl ester standards (all above 99\% purity) used for gas chromatography (GC) analysis were palmitic (hexadecanoic acid), stearic (octadecanoic acid), oleic (cis-9-octadecenoic acid), and linoleic acids (cis-9,cis-12-octadecadienoic acid) from Supelco, Bellefonte, PA, USA. Lipase from C. antarctica B, supported in acrylic resin macrospores (CAL-B; Novozym $435^{\circledR} 10,000 \mathrm{PLU} / \mathrm{g}$ ), was donated by Novozymes. Silica gel (70-230 mesh) from Vetec (RJ, Brazil) was used as the adsorbent.

\section{Gas chromatography $(G C)$}

For the GC analysis, the samples were diluted in dichloromethane (Vetec, 99.5\% pure) and the instrument used was a Varian GC model 3300 (Kyoto, Japan) fitted with a flame ionization detector (FID). The column used was a ZB-5 polydimethyl siloxane fused silica open tubular column with $5 \%$ phenyl groups $(30 \mathrm{~m} \times 0.53 \mathrm{~mm} \times 1.5 \mu \mathrm{m})$. The initial temperature was $80^{\circ} \mathrm{C}(0.2 \mathrm{~min})$, increasing by $8{ }^{\circ} \mathrm{C} \min ^{-1}$ to $140{ }^{\circ} \mathrm{C}(2 \mathrm{~min})$, followed by an $8{ }^{\circ} \mathrm{C} \mathrm{min}^{-1}$ increase to $270{ }^{\circ} \mathrm{C}$, which was then maintained for $2 \mathrm{~min}$. The injector was heated to $250{ }^{\circ} \mathrm{C}$, and the detector was set at $280^{\circ} \mathrm{C}$.

\section{Nuclear magnetic resonance (NMR)}

The ${ }^{13} \mathrm{C}$ and ${ }^{1} \mathrm{H}$ NMR spectra were recorded on an AC Bruker spectrometer operating at $400 \mathrm{MHz}$ at room temperature using $\mathrm{CDCl}_{3}$ as the solvent. All chemical shifts

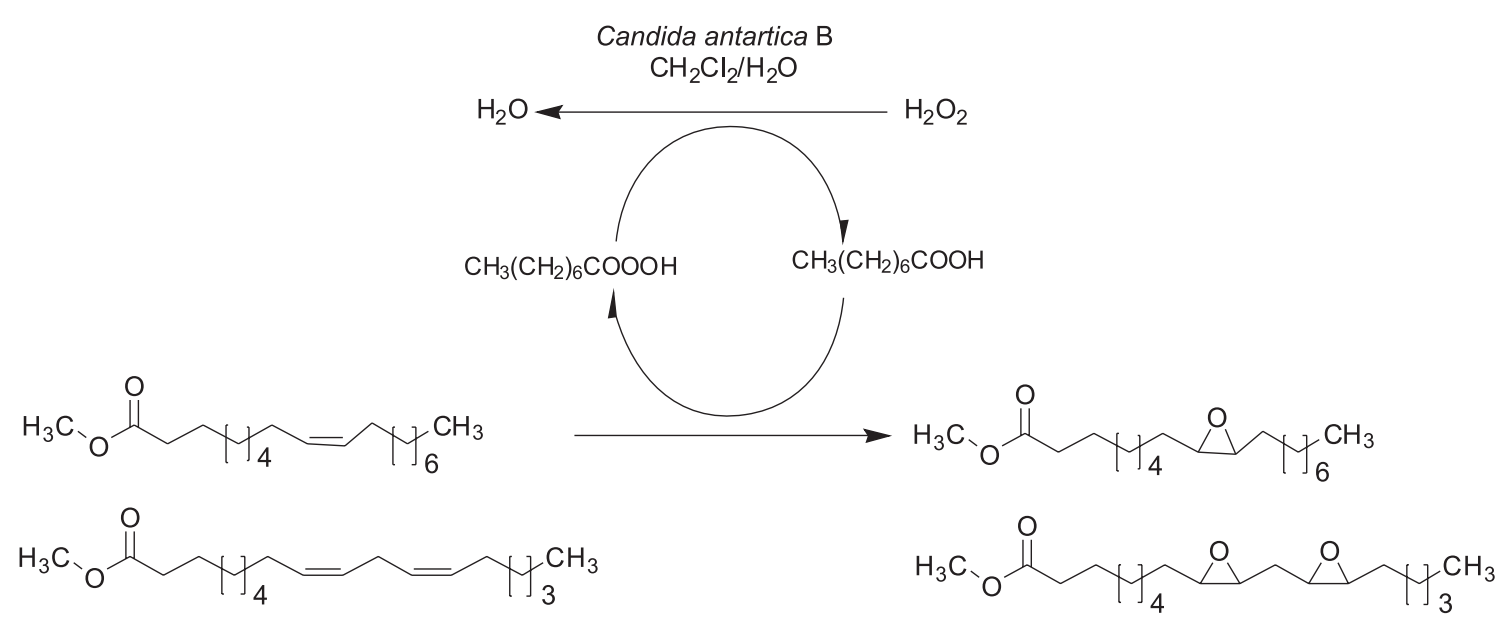

Figure 1. Chemo-enzymatic epoxidation of sunflower oil methyl esters (SOME). 
quoted were relative to tetramethylsilane using the positive downfield technique. For the determination of the degree of conversion, the relative area of the hydrogen atoms of the initial double bonds in the methyl esters were compared to those of the oxirane rings.

\section{Procedures}

\section{Methanolysis}

The sunflower oil was converted into the methyl esters by heating with $\mathrm{BF}_{3} \cdot \mathrm{MeOH}$ modified as recommended by the AOCS Ce 1c-89 standard methodology. ${ }^{23}$ The reaction was carried out with $100 \mathrm{~g}$ of sunflower oil and $100 \mathrm{~mL}$ of $2 \% \mathrm{NaOH}$ methanolic solution. The reaction mixture was kept at $70{ }^{\circ} \mathrm{C}$ for 20 min under reflux and with vigorous stirring. After saponification, $22 \mathrm{~mL}$ of $\mathrm{BF}_{3}$-methanol was added, and the mixture was kept at $70{ }^{\circ} \mathrm{C}$ for a further $10 \mathrm{~min}$. The methyl esters produced were extracted with $100 \mathrm{~mL}$ of heptane and dried over anhydrous $\mathrm{Na}_{2} \mathrm{SO}_{4}$. The solvent was then evaporated. The methyl esters derived from oleic acid and linoleic acids were used as reference standards in the GC analysis.

\section{General procedure for chemo-enzymatic epoxidation}

Sunflower oil methyl esters (SOME) (1 g), octanoic acid (10 mmol), lipase from C. antarctica B - CAL-B (100 mg), and aqueous hydrogen peroxide $(1 \mathrm{~mL}, 30 \%)$ were used in each chemo-enzymatic epoxidation reaction with vigorous stirring for $1-24 \mathrm{~h}$ at $30{ }^{\circ} \mathrm{C}$ in a round-bottomed flask equipped with a reflux condenser and a thermometer. Other experimental conditions are showed in Table 1.

Table 1. Experimental conditionsa for the chemo-enzymatic epoxidation of sunflower oil methyl esters

\begin{tabular}{lccc}
\hline Entry & $\mathrm{CH}_{2} \mathrm{Cl}_{2} / \mathrm{mL}$ & $\mathrm{H}_{2} \mathrm{O} / \mathrm{mL}$ & Caprylic acid $/ \mathrm{mmol}$ \\
\hline 1 & 6 & 5 & 10 \\
2 & 6 & 5 & - \\
3 & 6 & - & 10 \\
\hline
\end{tabular}

${ }^{\mathrm{a} S}$ Sunflower oil methyl ester (1g), CAL-B (100 mg), $\mathrm{H}_{2} \mathrm{O}_{2}(1 \mathrm{~mL}, 30 \%)$, $1-24 \mathrm{~h}$ at $30^{\circ} \mathrm{C}$.

After refluxing, the lipase was separated by filtration. CAL-B was reused 10 times in successive experiments at $24 \mathrm{~h}$ intervals. Methyl oleate and methyl linoleate were epoxidized using the same procedures.

The degrees of conversion were monitored via the iodine index (II) determination (AOCS Cd 1d-92), gas chromatography (GC), thin layer chromatography (TLC), hydrogen nuclear magnetic resonance ( $\left.{ }^{1} \mathrm{H} N M R\right)$, and carbon nuclear magnetic resonance $\left({ }^{13} \mathrm{C} \mathrm{NMR}\right)$.
Purification of the reaction products was carried out using adsorption column chromatography $(50 \mathrm{~cm} \times 2.5 \mathrm{~cm}$ i.d. $)$. Silica gel (70-230 mesh) was used as the stationary phase, and $n$-hexane and ethyl acetate in 100:0, 90:10, 85:15, $83: 17$, and $80: 20 \mathrm{v} / \mathrm{v}$ compositions were used as the eluents.

\section{Results and Discussion}

Epoxides derived from methyl esters of sunflower oil were obtained using lipase from Candida antarctica B (CALB) and aqueous $\mathrm{H}_{2} \mathrm{O}_{2}(30 \%)$, in the presence or absence of an acyl donor (caprylic acid). Two different systems, biphasic $\left(\mathrm{CH}_{2} \mathrm{Cl}_{2} / \mathrm{H}_{2} \mathrm{O}\right)$ and monophasic $\left(\mathrm{CH}_{2} \mathrm{Cl}_{2}\right)$, were applied and compared. The ratios of sunflower oil methyl esters to the corresponding formed epoxides were determined by gas chromatography (GC). The formed products were the same using the mono- and biphasic systems.

At the end of each reaction, the products were separated using column chromatography, and the degree of conversion was calculated through ${ }^{1} \mathrm{H}$ NMR spectroscopy. Two isolated fractions were identified as being the monoand di- epoxystearates (Figures 2A and 2B, respectively). The degrees of conversion obtained for the isolated monoepoxystearate and diepoxystearate were $>90$ and $>99 \%$, respectively. The monoepoxystearate showed a signal at $2.90 \mathrm{ppm}$, corresponding to the hydrogen of the oxirane ring corresponding to $\mathrm{C} 9$ and $\mathrm{C} 10$ (Figure 2A). The diepoxystearate showed an additional peak at $3.10 \mathrm{ppm}$ (Figure 2B).

The isolated diepoxystearate ${ }^{13} \mathrm{C}$ NMR spectra showed a peak at $34.50 \mathrm{ppm}$, which was assigned to the methylenic carbon between the two oxirane rings (C11 in Figure 2B), in addition to peaks at 54 and $56.8 \mathrm{ppm}$, which correspond to the methinic carbons of the oxirane rings $(\mathrm{C} 9, \mathrm{C} 10$ and C12, C-13 in Figure 2B).
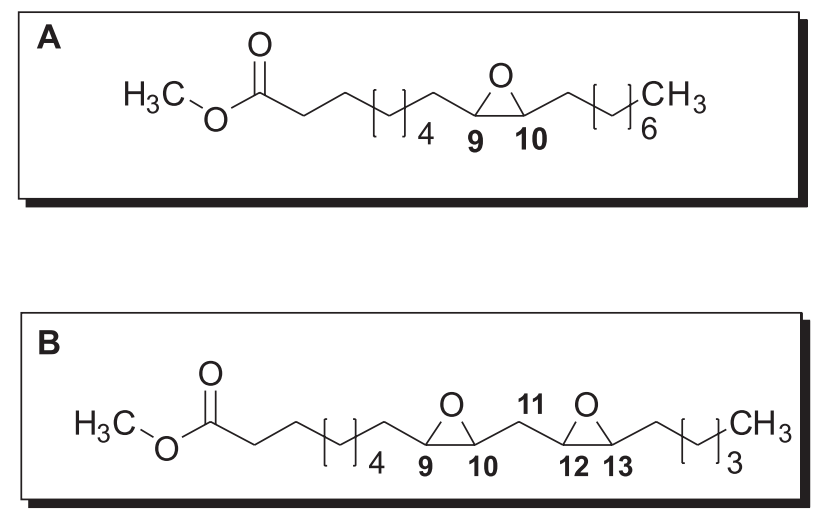

Figure 2. Structures assigned by ${ }^{1} \mathrm{H}$ NMR and ${ }^{13} \mathrm{C}$ NMR to the purified products $\left(400 \mathrm{MHz}, \mathrm{CDCl}_{3}\right.$ ). (A) methyl monoepoxystearate and (B) methyl diepoxystearate. 


\section{Comparison between mono and biphasic system}

The experiments involving the mono- and biphasic systems were carried out using $\mathrm{CH}_{2} \mathrm{Cl}_{2}(6 \mathrm{~mL})$ since the epoxy compounds formed are soluble in this solvent and can be easily recovered.

The monophasic $\left(\mathrm{CH}_{2} \mathrm{Cl}_{2}\right)$ and biphasic $\left(\mathrm{CH}_{2} \mathrm{Cl}_{2} / \mathrm{H}_{2} \mathrm{O}\right)$ systems were compared, and the addition of caprylic acid for the production of peracid, an epoxidation precursor, was also investigated. It is well documented in epoxidation that preparation of peroxyacids from vegetable oils is very feasible under mild conditions. ${ }^{18}$

Using classical epoxidation by chemical methods, the oxirane ring may open as a consequence of the strong acid used to catalyze the peracid formation, resulting in unsatisfactory consequences, including the formation of diols as byproducts. ${ }^{18}$

In the chemo-enzymatic epoxidation of the SOME, no secondary reactions were observed, and the products showed high oxirane oxygen contents. Thus, the reaction selectivity was higher than $99 \%$ in all reactions, with partial or total conversion of the unsaturated bond into the corresponding epoxides.

${ }^{1} \mathrm{H}$ NMR spectra obtained after using the monophasic system revealed the total conversion (>99\%) to the epoxidized products. Using the biphasic system total conversion was achieved after $16 \mathrm{~h}$ and with the addition of caprylic acid the total reaction time was the same. The reaction time was shorter using the monophasic system (Figure 3). Similar results were observed by Törnvall et $a l .{ }^{16}$ during the chemo-enzymatic epoxidation of fatty acids.

Studies on the influence of the acyl donor in the in situ peracid formation indicated that the use of fatty

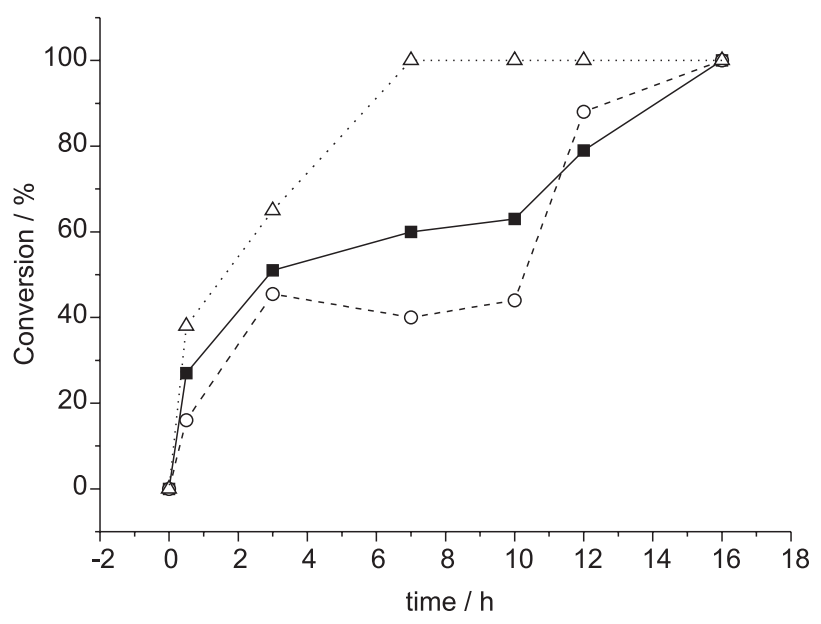

Figure 3. Degree conversion of the chemo-enzymatic epoxidation of SOME with Candida antarctica B lipase using biphasic system (O), monophasic system with caprylic acid $(\triangle)$ and biphasic system with caprylic acid (ם). linear carboxylic acids favors the conversion into the corresponding epoxides. ${ }^{17,22}$

It has been described that CAL-B efficiently hydrolyzes triacylglycerols because it produces free fatty acids that form peracids in the presence of hydrogen peroxide, which then epoxidize the unsaturated bonds. ${ }^{24}$ The reactivity and concentration of the peracid may also be responsible for lipase denaturation. ${ }^{25}$ With the use of the biphasic system, the peracid formed in situ was dissolved in water, reducing lipase denaturation. ${ }^{16}$ The advantage of using the biphasic system (water/organic solvent) over the monophasic system (organic solvent) is the possibility to reuse the biocatalyst. The results obtained in this study are given in Figure 4.

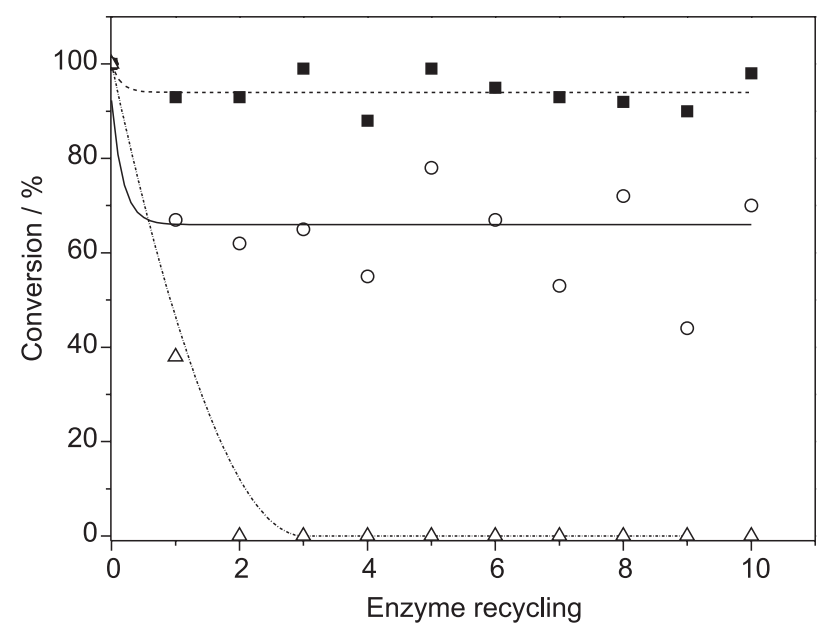

Figure 4. Reuse of Candida antarctica B lipase in chemo-enzymatic epoxidation of sunflower oil methyl ester in biphasic system (ם); and with caprylic acid as the acyl donor in the monophasic system $(\triangle)$ and in the biphasic system (O).

Using the monophasic system, the enzymatic activity was completely absence after the second reuse. However, using the biphasic system and with the addition of caprylic acid in the reaction, the lipase was reused at least ten times without losing its activity and the epoxides were formed in high yields (90-99\%). Similar results were achieved by Du et al. ${ }^{1}$ where the lipase was reused 100 times in the enzymatic transesterification of soybean oil with ethyl acetate, with a $92 \%$ conversion into the product. Another important result obtained here was the non-cleavage of the oxirane rings, which may occur in the chemical epoxidation of some oils and esters. ${ }^{26,27}$ In the ${ }^{1} \mathrm{H}$ and ${ }^{13} \mathrm{C}$ NMR spectra, there was no signal corresponding to the hydrogen or carbon atoms of the hydroxyl groups.

The proposed mechanism for the oxidation of the SOME using the biphasic and monophasic systems with caprylic acid as the acyl donor is shown in Figure 1. 


\section{Conclusions}

In this study, peracids were obtained by perhydrolysis of methyl esters derived from sunflower oil under mild conditions catalyzed by Candida antarctica B lipase.

The results showed that chemo-enzymatic methods are extremely efficient in the synthesis of epoxides from unsaturated methyl esters. The products obtained were fully characterized and quantified. High degrees of conversion and selectivity were achieved under the applied conditions using the mono- and diepoxystearates. These results are important for the chemical industry and present the possibility for the production of oil derivatives through a cleaner technology, using lipase as the catalyst and with a reduction in the use of undesirable chemical reagents.

The use of biphasic and monophasic systems leads to a high degree of conversion to the epoxides, as well as the possibility to reuse the system at least ten times. The presence of caprylic acid as a peracid precursor is of crucial importance in obtaining the products in high yields (>99\%).

In summary, the epoxidation of methyl esters derived from sunflower oil was successfully achieved under mild conditions.

\section{Acknowledgments}

This work was supported by the Universidade de Santa Cruz do Sul (UNISC, Brazil), Universidade Federal de Santa Catarina (UFSC, Brazil), Fundo de Apoio a Pesquisa (FAP, UNISC), Financiadora de Estudos e Projetos (FINEP), Conselho Nacional de Desenvolvimento Científico e Tecnológico (CNPq) and Fundação de Amparo a Pesquisa do Estado do Rio Grande do Sul (FAPERGS). T. B. B, M. G. N. and L. R. S. L. would like to thank CNPq for their scholarships and we are also grateful to Novozymes for generously donating the lipase.

\section{References}

1. Du, W.; Xu, Y.;Liu, D.; Zeng, J.; J. Mol. Catal. 2004, 30, 125.

2. Martinelli, M; Schneider, R. C. S.; Baldissarelli, V.Z; Trombeta, F.; Caramão, E. B.; J. Chromatogr., A 2003, 985, 313.

3. Martinelli, M.; Schneider, R. C. S.; Baldissarelli, V. Z.; Holleben, M. L.; Caramão, E. B.; J. Am. Oil Chem. Soc. 2005, 4,82 .
4. Shmid, A.; Dordick, J. S.; Hauer, B. K.; Kiener, A.; Wubbolts, M.; Witholt, B.; Nature 2001, 409, 258.

5. Haki, G. D.; Rakshit, S. K.; Bioresour.Technol. 2003, 89, 17.

6. Hasan, F.; Shah, A. A.; Hameed, A. I.; Enzyme Microb. Technol. 2006, 39, 235.

7. Gandhi, N. N.; J. Am. Oil Chem. Soc. 1997, 74, 621.

8. Kiatsimkul, P.; Sutterlin, W. R.; Suppes, G. J.; J. Mol. Catal. B: Enzym. 2006, 41, 55.

9. Suarez, P. A. Z.; Plentz-Meneghrtti, S. M. P.; Meneghetti, M. R.; Wolf, C. R.; Quim. Nova 2007, 30, 667.

10. Isbilir. S. S.; Ozcan, H. M.; Yagar, H.; J. Am. Oil Chem. Soc. 2008, 85, 227.

11. Rusch gen Klaas, M.; Warwel, S.; J. Am. Oil Chem. Soc. 1995, 73, 1453.

12. Björkling, F.; Frykaman, H.; Godtfredsen, S. E.; Kirk, O.; Tetrahedron 1992, 48, 4587.

13. Slayden, S. W.; Liebman, J. F.; Sawaky, Y.; The Hydroxyl, Ether and Peroxide Groups, Patai, S., ed.; Wiley: Chichester, 1993.

14. Björkling, F.; Godtfredsen, S. E.; Kirk, O.; J. Chem. Soc. Chem. Commun. 1990, 1301.

15. Rusch gen Klaas, M.; Warwel, S.; J. Mol. Catal. A: Chemical. 1997, 117, 311.

16. Törnvall, U.; Ornellana-Coca, C.; Hatti-Kaul, R.; Albercreutz, D.; Enzyme Microb. Technol. 2007, 40, 447.

17. Rusch gen Klaas, M.; Warwel, S.; Ind. Crop Prod. 1999, 9, 125.

18. Carboni-Oerlemans, C.; Maria, P. D.; Tuin, B.; Bargeman, G.; Meer, A.; Gemert, R.; J. Biotechnol. 2006, 126, 140.

19. Piazza, G. J.; Nuñez, A.; Foglia, T. A.; J. Mol. Catal. B: Enzym. 2003, 21, 143.

20. Rios, L. A.; Weckes, H. S.; Schuster, H.; Hoelderich, W. F.; Appl.Catal. A: Gen. 2005, 284, 1-2, 155.

21. Borzani, W.; Biotecnologia Industrial. Fundamentos, $1^{\mathrm{a}}$. Ed, Edgard Blucher: São Paulo, Brasil, 2001, 151-171, v.1.

22. Moreira, M. A.; Bitencourt, T. B.; Nascimento, M. G.; Synth. Commun. 2005, 35, 2107.

23. Official Methods and Recommended Practices of the AOCS; $15^{\text {th }}$ ed., Ce 1c-89, Champaign, 1997.

24. Warwel, S.; J. Am. Oil Chem. Soc. 1996, 73, 1453.

25. Yadav, G. D.; Devi, K. M.; Biochem. Eng. J. 2002, 10, 93.

26. Goud, V. V.; Patwardhan, A. V.; Pradhan, N. C.; Bioresour. Technol. 2006, 97, 1365.

27. Okieimen, F. E.; Bakare, O. I.; Okieimen, C. O.; Ind. Crop. Prod. 2002, 15, 139.

Received: January 29, 2009 Web Release Date: August 20, 2009 